\title{
STUDY OF AUTOPSY BASED SUICIDAL HANGING
}

\author{
NIRUPAMA TALUKDER ${ }^{1}$, KH. A. KARIM ${ }^{2}$, TARANA CHOWDHURY ${ }^{3}$, ASHAN HABIB ${ }^{4}$, AZREEN MOMEN CHOWDHURY ${ }^{5}$, \\ KAWSER PERVEEN ${ }^{6}$
}

${ }^{1}$ Associate Professor, Department of Forensic Medicine, Uttara Adhunik Medical College, Dhaka

${ }^{2}$ Professor \& Head, Department of Forensic Medicine, Popular Medical College, Dhaka

${ }^{3}$ Lecturer, Department of Forensic Medicine, Uttara Adhunik Medical College, Dhaka

${ }^{4}$ Department of Forensic Medicine, Uttara Adhunik Medical College, Dhaka

${ }^{5}$ Assistant Professor, Department of Community Medicine, Uttara Adhunik Medical College, Dhaka

${ }^{6}$ Associate Professor, Department of Pathology, Uttara Adhunik Medical College, Dhaka

\begin{abstract}
Introduction: Hanging is one of the most commonly used methods for suicide in most countries. Commission of suicide by hanging is increasing in the people of Bangladesh. Suicidal hanging is detrimental to social health. Appropriate measures to prevent it are essential.
\end{abstract}

Objectives: To find out the demography, cause and nature of suicidal hanging.

Study design: It is a cross sectional type of descriptive study.

Setting: Data was collected on predesigned proformas from postmortem reports recorded by the students of DFM and MD in Forensic Medicine at Dhaka medical college during their course.

Subject: Autopsy performed on the cases of suicidal hanging at Dhaka Medical College Morgue from September, 2011 to June, 2013.

Result: Out of 100 cases, eighty two (82\%) were female and the most commonest (50\%) age group were from 11-20 years. In 18(18\%) cases Dopatta were the commonest material used for hanging. Quarrel with husband 12(12\%) were the predominant cause to destroy life. In ninety (90\%) cases had complete suspension where the most commonest situation of gap was on the back (38.89\%). During autopsy of suicidal hanging there were injuries on the body of deceased in few cases. But these injuries did not result in death of the victim.

Key words: Dhaka Medical College Morgue, Autopsy, Hanging, Suicide.

(Bangladesh J Physiol Pharmacol 2014;30(2):14-17)

\section{INTRODUCTION}

Suicide means self murder. Attempted suicide is an unlawful act and the person is held responsible for the immediate consequences of the act. ${ }^{1}$ Knowledge on suicidal phenomenon is constantly increasing. ${ }^{2}$ The method used to commit the index suicide attempt classified as soft or hard. 'Hard' were the methods imagined to cause death through pain, tearing the body to pieces, bleeding to death, choking, i.e. hanging oneself, throwing oneself under a train or out of a window, shooting oneself, poisoning, inducing an embolism. The 'soft' methods instead were swallowing medications, cutting one's veins, abandoning oneself to the current to the point of drowning, suffocating with a plastic bag, and turning on the gas. All these 'soft' methods can be atrocious. ${ }^{2}$ Hanging is one of the most commonly used methods for suicide worldwide. Its incidence has increased over the last 30 years. ${ }^{3}$ Hanging is a process in which the body is suspended with

Address for correspondence: Nirupama Talukder, Associate Professor, Department of Forensic Medicine, Uttara Adhunik Medical College, Dhaka a ligature around neck which causes constriction of the air passage preventing exchange of air between the atmosphere and the alveoli of lungs, leading to asphyxia and death. ${ }^{4}$ The constricting force is either the weight of the whole body or weight of head alone. ${ }^{4}$ Hanging is usually suicidal. ${ }^{5}$ Cause of death are asphyxia, venous congestion, combined asphyxia and venous congestion, cerebral ischemia, shock, fracture or dislocation of the cervical vertebrae. $^{4}$ It is very unusual for the cervical spine to be broken in suicidal hanging unless there has been an unusually long drop. ${ }^{6}$ Causes of suicidal death in our country regarding the risk factors are low status in society, lack of decision making, marital conflicts, chronic illness, mental illness. Suicide among unmarried women of reproductive age may be linked to extramarital sex-forced or consensual and subsequent unwanted pregnancy. ${ }^{7}$

\section{MATERIALS AND METHODS}

This study was conducted on 100 cases of suicidal hanging at Dhaka Medical College Mortuary. Data was collected on predesigned proformas from autopsy 
reports recorded by the students of Diploma and MD course in Forensic Medicine at Dhaka Medical College from March 2011 to June 2013 with their verbal consent. We collected demographic data, cause, type of hanging, nature of ligature material used, situation of gap on the neck and any injuries on the other parts of the body. The collected data was entered in SPSS software (12 versions) and analyzed. The obtained data were checked, verified and edited before tabulation. Results were presented in diagram and tables keeping in mind the objectives of the study.

\section{RESULT}

Out of 100 cases, eighty two (82\%) were female (Figure-1). It is observed that age of the victim was between 1 to 55 years. Among them age group 11-20 years were most predominant $50(50 \%)$ followed by ages from 21-30 years 40 (40\%) Table-1. Mean age of 22.20 year and a standard deviation of 7.01 year. In most cases $18(18 \%)$ dopatta were the commonest material for suspension of the body. Rope 10(10\%), Sharee $8(8 \%)$, other9 $(9 \%)$ were also used as ligature material and in $55(55 \%)$ cases nature of materials were not mentioned (Table -2). Quarrel with spouse 12(12 $\%$ ) was the commonest cause. Family disharmony $2(2 \%)$, other $9(9 \%)$, not mentioned in $77(77 \%)$ cases. (Table-3). In 90(90\%) cases had complete suspension and $02(2 \%)$ were of incomplete/ partial suspension and $8(8 \%)$ were not mentioned (Table-4). Considering the location of gap most were situated on the back $35(35 \%)$ followed by left side of neck $29(32.22 \%)$. ChiSquare test was done but not significant. A p-value of less than 0.05 was considered as statistically significant.

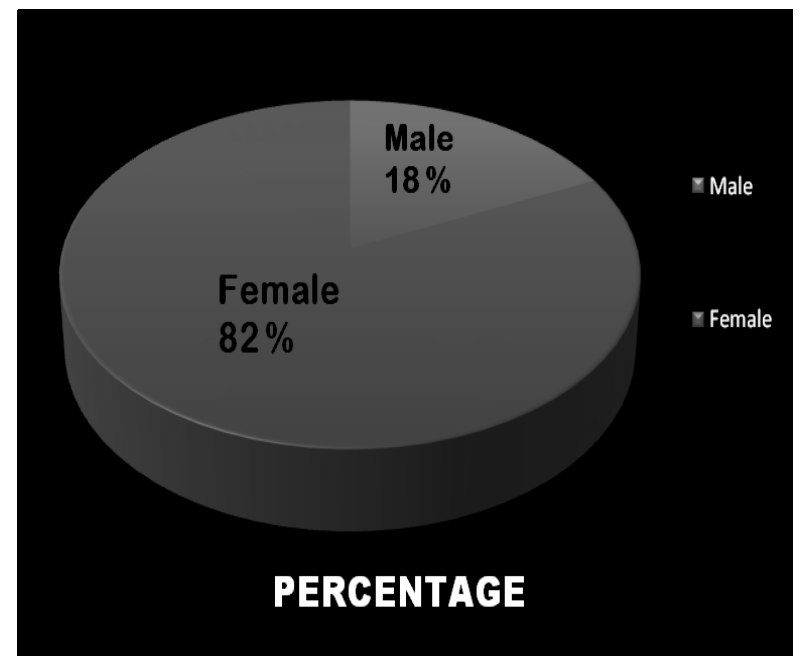

Figure : 1

Showing distribution of patient by $\operatorname{sex}(n=100)$.
Table I

Distribution of patient by age $(n=100)$

\begin{tabular}{|l|c|l|}
\hline Age in year & No & Percentage \\
\hline $0-10$ & 1 & $1 \%$ \\
\hline $11-20$ & 50 & $50 \%$ \\
\hline $21-30$ & 40 & $40 \%$ \\
\hline $31-40$ & 7 & $7 \%$ \\
\hline $41-50$ & 1 & $1 \%$ \\
\hline $51-60$ & 1 & $1 \%$ \\
\hline Total & 100 & $100 \%$ \\
\hline
\end{tabular}

Table : II

Nature of Ligature material used by victim for hanging $(n=100)$.

\begin{tabular}{|l|c|c|}
\hline $\begin{array}{l}\text { Ligature } \\
\text { materials }\end{array}$ & No & Percentage \\
\hline Sharee & 8 & 8.0 \\
\hline Dopatta & 18 & 18.0 \\
\hline Rope & 10 & 10.0 \\
\hline Others & 9 & 9.0 \\
\hline Undetermined & 55 & 55.0 \\
\hline Total & 100 & 100.0 \\
\hline
\end{tabular}

Table : III

Predisposing cause of hanging $(n=100)$.

\begin{tabular}{|l|c|c|}
\hline Cause & No & Percentage \\
\hline Undetermined & 77 & 77.0 \\
\hline Quarrel with spouse & 12 & 12.0 \\
\hline Family disharmony & 2 & 2.0 \\
\hline Others & 9 & 9.0 \\
\hline Total & 100 & 100.0 \\
\hline
\end{tabular}

Table : IV

Classification of victim by degree of suspension of the body $(n=100)$.

\begin{tabular}{|l|l|c|}
\hline Type & No & Percentage \\
\hline Complete & 90 & $90 \%$ \\
\hline Partial & 2 & $2 \%$ \\
\hline Not mentioned & 8 & $8 \%$ \\
\hline Total & 100 & $100 \%$ \\
\hline
\end{tabular}




\section{DISCUSSION}

Suicide by hanging is the act of intentionally killing oneself via suspension from an anchor point by a ligature. Hanging is a very simple yet highly effective suicide method. It is one of the most commonly used methods and has high mortality rate. ${ }^{8}$ Among the different modes of suicide in Bangladesh one of the commonest mode is hanging. ${ }^{9}$ Unlike old decades, female are only engaged in domestic work. Moreover they are involved in national and international important activities with great success. Instead of relative improvement of social status, they are not completely free from familial delimni in our country yet. Therefore opposite picture is revealed in another group of females who are used to be abused for simple mistakes in domestic work, marital conflict in married women and other familial disharmony commonly in low socioeconomic society which lead to take desperate decision like suicide to rid her. This study revealed that hanging was the commonest method of suicide in young women, it differs the findings of Lorna Duckworth ${ }^{10}$ and quarrel with spouse was the commonest cause of suicidal hanging, this finding corresponds with the study conducted in Dhaka Medical College. ${ }^{11}$ Owing to lack of experience of the investigating officers in the field of medico-legal work, the inquest reports prepared by them are usually inadequate and incomplete. These deficiencies lead to difficulty in collection of accurate statistical data such as cause and material used were undetermined in some cases in this study. This finding is similar that was found in a study conducted in Dhaka Medical College from the year 1992-1996. ${ }^{12}$ Current study revealed that women between $11-20$ years were the most affected age group. Emotional factor from different source triggering suicide among these ages. This finding contradict that was found in both the study conducted in Dhaka Medical College and Sir Salimullah Medical College. ${ }^{9,11}$ In this study only one case was found above 50 years and no case was above 60 year. It was observed that Dopatta/Orna was the commonest ligature material used for hanging. Similar findings were observed in the study conducted in Sir Salimullah Medical College. ${ }^{11}$ The materials required are easily available, and a wide range of ligatures can be used. Because of this, it is considered a difficult method to prevent. $^{8}$ Traditional dress of Bangladesh is Salwar Kamiz and Orna. Easy availability of this material was the reason of its highest percentage among the materials. This finding differs from that study conducted in Forensic Medicine department of Dhaka Medical College and in 24 coroner's jurisdiction of England, where rope was common ligature material in hanging. $3,9,13$ Sometimes people bent on suicide have attempted other methods. Therefore, the body may have cuts and other injuries. There may be other injuries which have been accidental in that the person may have sustained them when throwing himself from a table or a chair. ${ }^{14}$ Bruise and abrasion constitute only $3.33 \%$ in this study due to impact with surrounding hard objects. In ninety percent of total cases bodies were completely suspended. Typical method of selfsuspension is to attach a thin rope to a high point such as a ceiling beam or a staircase. The lower end is formed into either a fixed loop or a slip knot, which is placed around the neck while the intending suicide stands on a chair or other support. On jumping off or kicking away the support, the victim is then suspended with all or most of his weight upon the rope. ${ }^{15}$

\section{LIMITATIONS OF THE STUDY}

In our study the greatest drawback was the lack of information about cause and nature of ligature material used in suicide by hanging.These information were not available in inquest reports. Therefore we have to analyze these data with small group subjects.

\section{CONCLUSION}

Suicide by hanging is rising among young female in our country. Both government and family have to be cordial to exclude the causative factors and prevent the suicidal behavior before it become worse. Social awareness, education and involvement in encouraging activities of young female may reduce the rate of suicide by developing the emotional stability at this age. Visiting scene of occurrence by Forensic Pathologist and specialized training for investigating officer need to be considered important to achieve more evidence and thus reach our goal.

\section{REFERENCES}

1. Parikh's CK. Parikh's Text book Medical Jurisprudence Forensic Medicine and Toxicology, Injuries- MEDICOLEGAL Aspects, $6^{\text {th }}$ ed, 1999, CBS Publishers \& distributor, 456.

2. Quando i mass media parlano di suicidio-Psychomedia available at: www.psychomedia.it/pm/answer/suicid/grava.htm

3. Gunnell D, Bennewith O, HawtonK, Simkin S, Kapur N. The epidemiology and prevention of suicide by hanging: a systemic review. Int J Epidemiol. 2005; 34(2): 433-442.

4. Nandy A. Principles of Forensic Medicine including Toxicology, Violent Asphyxial Death, $3^{\text {rd }}$ edt, 2010, New Central book Agency (P) Ltd, p. 517.

5. Modi's Medical Jurisprudence and Toxicology, Death from asphyxia, 23 $3^{\text {rd }}$ edt, 2006, Lexis Nexis, New Delhi, 566-567.

6. Shepherd R, Simpson's Forensic Medicine, Asphyxia, 12th ed, 2003, Arnold, London, 100.

7. Johnston HB, Naved RT. Spousal violence in Bangladesh: ICDDR,B Health Popul Nutr 2008; 26(3): 366-377.

8. Suicide by hanging- Wikipedia, the free encyclopedia p.1.

9. Hossain MN. Suicidal death autopsy analysis at Dhaka Medical College. Bangladesh Med J 2011; 40(1):.

10. Duckworth L. Frost's Meditations, Hanging 'now the most common form of suicide', 1 May 2001. 5

available at: www.martinfrost.ws/htmlfiles/mar2009/methodscommit-suicide.html. 
11. Ahmed M, Hossain MZ. Hanging as a method of suicide retrospective analysis of postmortem cases. JAFMC Bangladesh 2010; 6(2): 39.

12. Mostaque SR, Tejendra DC. Pattern of Suicidal Hanging cases of Forensic Medicine Department of DMC. Bangladesh Med J 2004; 33(4): 116.

13. Bennewith O, Gunnell D, Kapur N, Turnbull P, Simkin S, et al. Suicide by hanging: multicentre study based on coroner's records in England. available at: www ncbi.nim.nih.gov/pubmed/15738509.

14. Mant KA. Taylor's Principles and Practice of Medical Jurisprudence, Mechanical asphyxia, $13^{\text {th }}$ ed, 1984, Churchill Livingstone, London, 316

15. Pekka S, Knight B. Knight's Forensic Pathology, Fatal pressure on the neck, $3^{\text {rd }}$ ed, 2004, Hodder Arnold, part of Hachette Livre UK. 384 